\title{
Entrepreneurship Game Apps to Enhancement Student Skill Thinking Analytic in Class Online
}

\author{
https://doi.org/10.3991/ijim.v15i08.21575 \\ Heri Pratikto, Rizal Hanafiya, Muhammad Ashar ( $\left.{ }^{\bowtie}\right)$, \\ Muhammad Iqbal Akbar, Yudi Tri Harsono \\ Universitas Negeri Malang, Malang, Indonesia \\ Muhammad.ashar.fteum.ac.id
}

\begin{abstract}
The use of educational entrepreneurship game apps as a medium for online class for students to improve analytical skills regarding business processes. Learning that is only through gamification in game learning. This learning is carried out on a number of students who have the ability to play games well. There is also a desire to study business without using entrepreneurship textbooks as the object of this study. Game based mobile apps development using entrepreneurial learning materials such as laundry and beverage sales is designed using the Design Thinking Process method. With a game prototype made according to the real market location and market potential which is quite profitable. Determination of initial capital is very important in this educational game to successfully play the game until the final level. (there are 5 trial levels). The results obtained from this game play show an increase in entrepreneurial analysis in students with the ability to answer post-test questions well with an average of 88.2 percent with an average game time of 42.8 minutes per level.
\end{abstract}

Keywords-Educational Games, Design Thinking Process, Media, Entrepreneurship, Training

\section{Introduction}

One of the state's efforts to fulfill quality human resources is the development of vocational education. According to the explanation of Law Number 20 of 2003 Article 15 , vocational education is secondary education that prepares students, especially to work in certain fields. One of vocational education is Vocational High School (SMK).

Creative and Entrepreneurship Products have the aim of developing knowledge and training skills-based arts, technology and economics. Creative and Entrepreneurship Products in classroom learning often students experience difficulties in studying Creative Products and Entrepreneurship, especially in business opportunity identification material. This can be seen from the small number of graduates/students who are interested in carrying out entrepreneurial activities related to the skills they are learning in the competency of their skills.

According to the data, the use of game media in schools as an alternative learning media is currently not optimal and tends to be rarely used. Sememtra vocational school 
students have sufficient ability to operate gamed downloaded on smartphones properly and are accustomed to using it. The reason for using games as a learning medium that needs to be tested on students is because games are a system where players are involved in artificial conflicts, limited by rules and the results can be quantified [10].

Furthermore, [3] defines the game as a system where players are bound by an abstract challenge, rules, interactivity, feedback that produces measurable results and can cause emotional reactions, so it can be concluded that games are a system used for fun, and bound to defined rules so that the player is conditioned in an artificial conflict with the aim of achieving an outcome measured by a score.

According to [7], games have enormous potential in building motivation in the learning process. In contrast to conventional learning methods, to foster learning motivation as much as in-game motivation, competent teachers / instructors are needed in managing the learning process. Based on this opinion, games can be made wrong.

Educational games are a type of game that is used to deliver learning materials or types of games with educational content. Educational games aim to provoke student interest in learning in a fun way. With happy feelings, it is hoped that students will find it easier to understand the subject matter presented. According to [9], educational games are games designed for learning, but still offer play and fun". Games can be called educational games when they integrate subject matter into their components and utilize left brain functions. In other words, educational games are games that are used to teach players.

This educational genre game aims to provoke children's interest in learning subject matter while playing. This genre refers more to the content and purpose of the game. In the process of making the game itself, it can be built from several elements. Jesse Schell [11] in The Art of Game Design Describes the basic elements of the game in four parts, the basic elements of the game are: (1) Aesthetic, (2) Story, (3) Mechanics, (4) Technology.

The learning process of educational games studied is the ability of students to learn entrepreneurship appropriately with a level of understanding and business analysis that is good enough to be used for learning anytime and anywhere but learning outcomes are obtained optimally. At least students are able to do market analysis, product sales process, know product value, determine business location and market potential and learn independently about the business model of loundry and beverage business so as to be able to provide the right conclusions about the type of business that is done in a game and produces a game score. perfectly. And the results of the quis analysis or practice questions are able to score an average score of passing in the learning class.

The purpose of this study is expected to use game media in entrepreneurship learning to provide the right solution for students in learning with alternative media so that learning time is not only at school but when and wherever the learning process can be used flexibly and does not limit the learning space. 


\section{Method}

The research and development method used in this research is the research and development method of Design Thinking. In this model there are three main activity functions, namely: 'Plan', 'Execute', and 'Synthesize'.

In making a product or application using the design thinking method, the following steps will be repeated as many times as needed to produce the appropriate product:

\section{Emphatize}

At this stage, observations and interviews are carried out to find out the point of view of potential users, observations and interviews are carried out on a number of students who have entrepreneurial experience and enjoy playing games in class online using game apps [1].

\section{Define}

At this stage, the needs and backgrounds of prospective users are defined that have been obtained from the results of observations and interviews that have been conducted. The list of user needs based on observations and interviews is as follows: (a). Users need illustrative learning media as a means of supporting learning. (b) users need innovative learning media as a means of increasing student enthusiasm for learning. (3) users are accustomed to using and operating a mobile device in the form of a smartphone [5].

\section{Ideate}

Based on the data that has been obtained in the form of facts in the field obtained through observations and interviews regarding student characteristics, the availability of facilities and infrastructure, as well as the teacher's need for illustrative learning media, researchers offer alternative solutions to develop mobile-based educational game learning media to help the process. learning in order to increase students' enthusiasm for learning by delivering illustrative and fun.

\section{Prototype}

Pre-existing ideas need to be implemented directly in an mobile apps application or trial product. It is necessary to produce a real product and possible use scenarios.

\section{Test}

From the product or trial application that has been made, an experiment will be carried out with the user. From user experience in using trial products, input will be obtained to make better products and make improvements to existing products. 


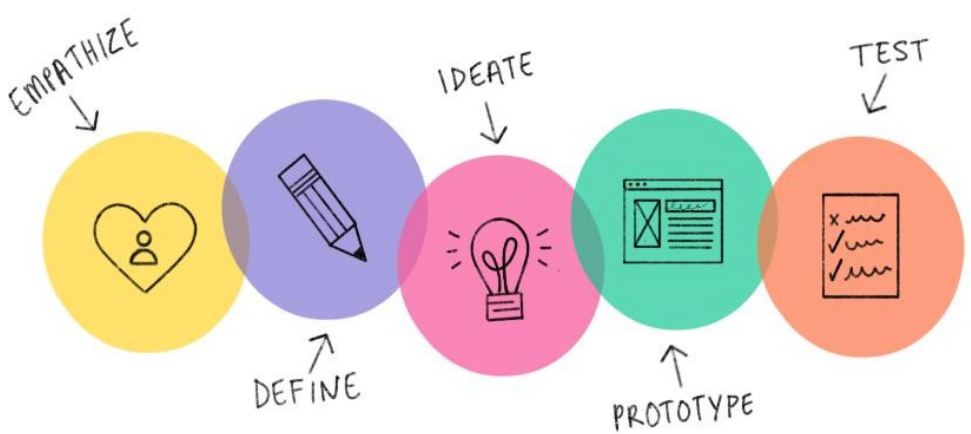

Fig. 1. Stages of design thinking in the laundry and beverage game

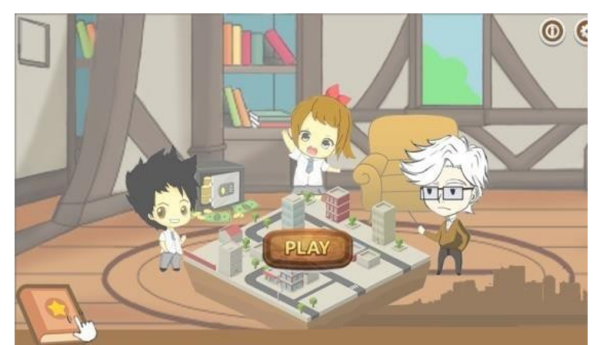

Home Page
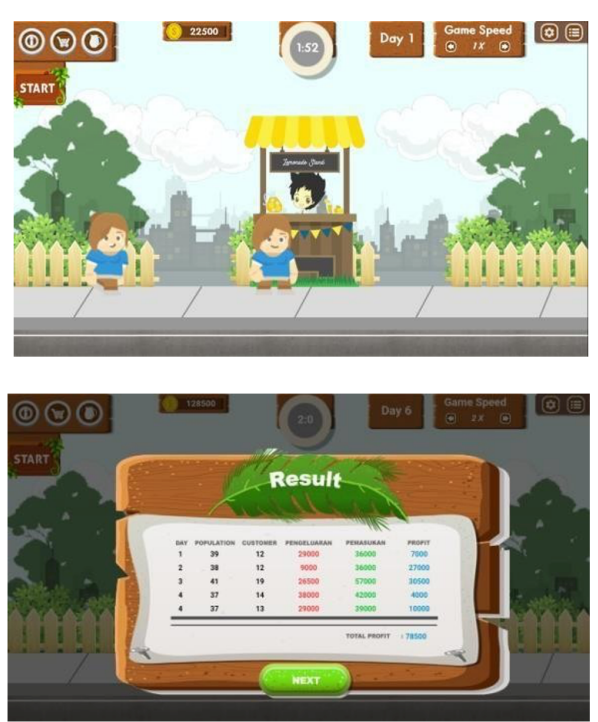

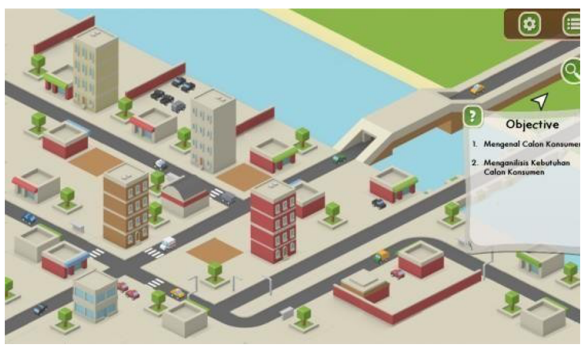

Market Target Location
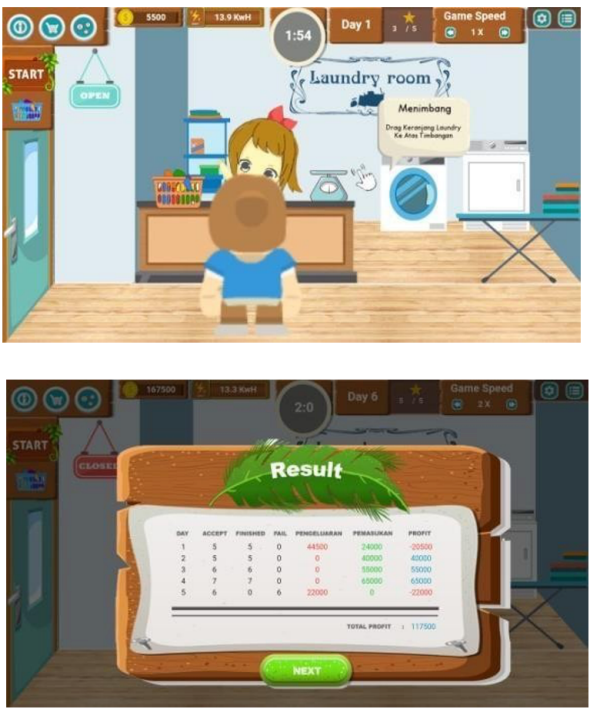

Fig. 2. Design drink and laundry business game apps 


\section{$3 \quad$ Results and Discussion}

\subsection{The results of developing a coding game}

1. The results of the validation test by media experts obtained results in the form of a percentage of $87.5 \%$ in the software engineering aspect, and a percentage of $91.6 \%$ in the visual communication design aspect.

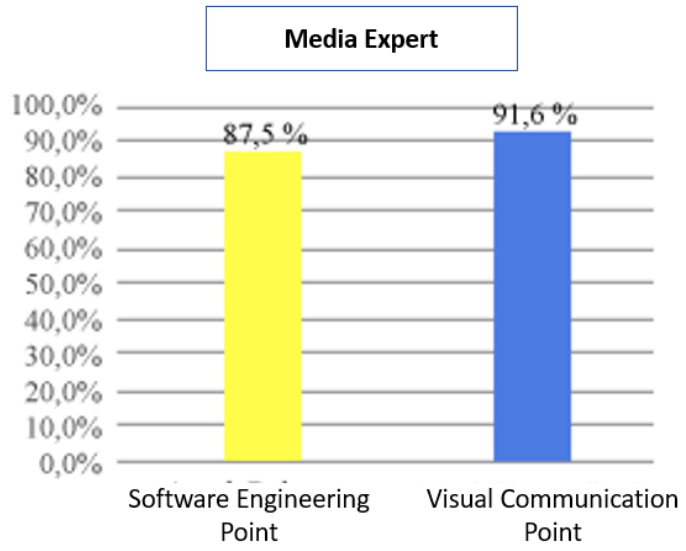

Fig. 3. Media expert validation graph

2. The results of the validation test by material experts obtained a percentage of $94.6 \%$ in the aspect of learning design, and a percentage of $95.8 \%$ in the aspect of visual education.

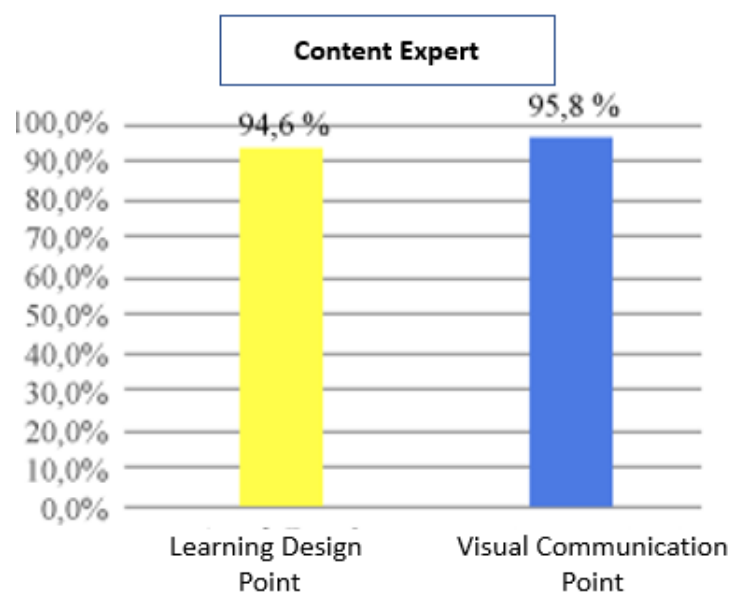

Fig. 4. Material expert validation graph 
3. The results of the validation test by material experts obtained a percentage of $94.6 \%$ in the aspect of learning design, and a percentage of $95.8 \%$ in the aspect of visual education.

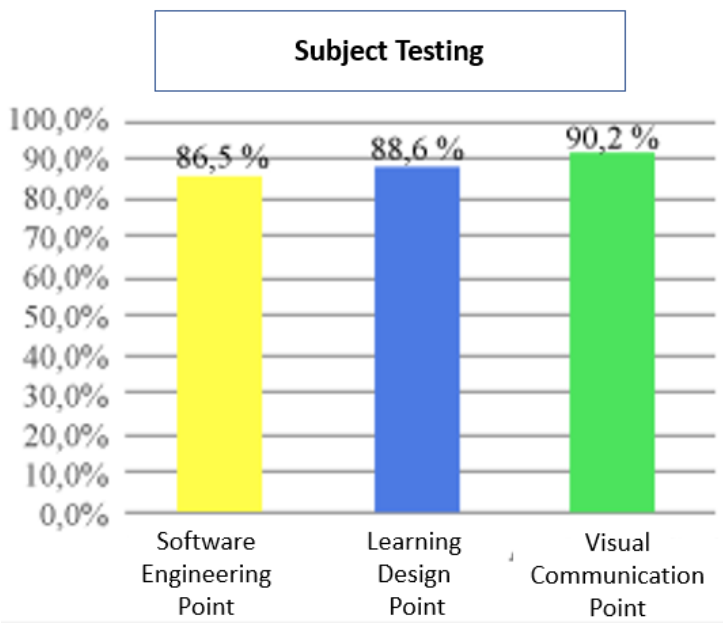

Fig. 5. Graph of trial subjects

4. The trials that have been done, obtained the final percentage of $90.0 \%$ by media experts, $95.0 \%$ by material experts, and $88.2 \%$ by test subjects.

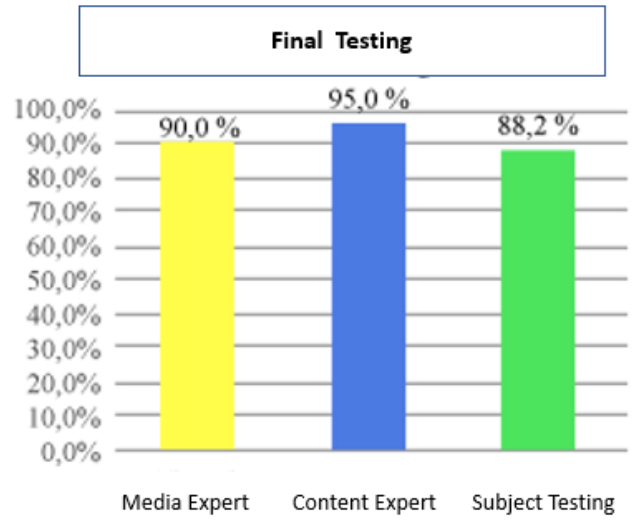

Fig. 6. Graph of final test results

5. Learning time with a correlation between understanding business materials shows an increase in analytical thinking skills with a learning time of 214 minutes of drinking business games and 253 minutes of laundry business games (average 42.8 minutes and 50.6 minutes respectively level of play). 


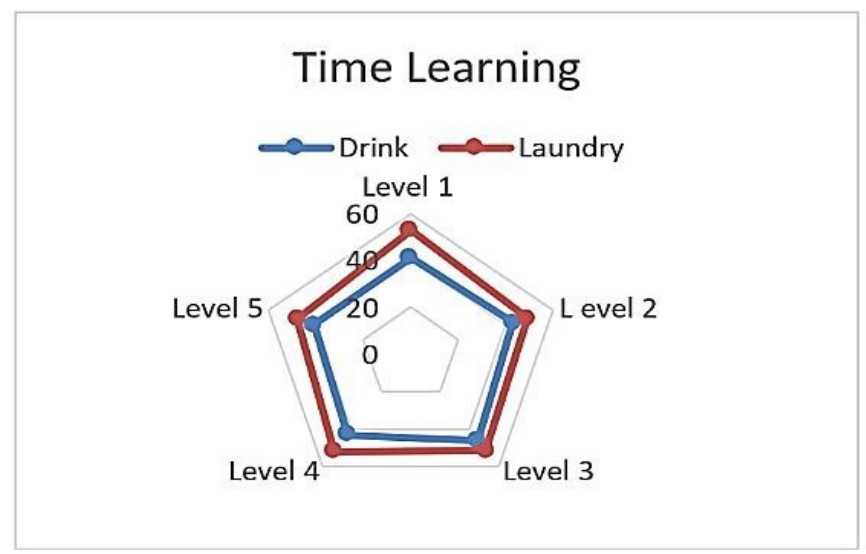

Fig. 7. Material expert validation graph

\section{Conclusion}

The use of game media in the entrepreneurial learning process shows effectiveness for students with an increase in good analytical thinking skills, on average $88.2 \%$ understand the concept of market analysis, business operating costs, determining basic prices, and profit analysis for both laundry and drink sale businesses. This increase in understanding is quite visible in the fast learning time with the process of giving gamification at each level which sequentially increases according to the stages of practical entrepreneurial learning. The need to increase the types of businesses and business models that are implanted in learning in game media in the future.

\section{$5 \quad$ References}

[1] Akbar, S. (2013). Instrumen Perangkat Pembelajaran. Bandung: PT. Remaja Rosdakarya.

[2] Henry, Samuel. (2010). Cerdas dengan Game: Panduan Praktis Bagi Orangtua dalam Mendampingi Anak Bermain Game. Jakarta: PT. Gramedia Pustaka Utama.

[3] Kapp, M. Karl. (2012). The Gamification of Learning and Instruction.Hoboken: Pfeiffer.

[4] Kusumo, G. R. (2018). Pengembangan Game Edukasi Berbasis Mobile Sebagai Media Pendukung Pembelajaran Untuk Mata Pelajaran Pemrograman Dasar Di SMK. Skripsi. Malang: FT UM. https://doi.org/10.17977/um034v29i2p161-176

[5] Mohammad Ismail, Ahmad Fuad Ibrahim, Mohd Rafi Yaacob, et. al. (2018). Determine Entrepreneurial Characteristics Using Mobile Android Gamer Freezer. iJIM - Vol. 12, No. 1, 2018. https://doi.org/10.3991/ijim.v12i1.7790

[6] Nurhariyanto. (2018). Pengembangan Media Game Edukasi Untuk Materi Rancang Bangun Jaringan Di SMKN 6 Malang. Skripsi. Malang: FT UM

[7] Nygren Eeva. (2018). Dynamics between Disturbances and Motivations in Educational Mobile Games. iJIM - Vol. 12, No. 3, 2018. https://doi.org/10.3991/ijim. v12i3.8490

[8] Plattner, Christoph M., Leifer L. (Ed). (2010). Design Thinking: Understand Improve Apply. New York City: Springer. 
Prensky, Marc. (2012). "From digital natives to digital wisdom: hopeful essays for 21 st century learning”. India: Corwin Press. https://doi.org/10.4135/9781483387765

[10] Salen, Erick Z. (2003). Rules of Play: Game Design Fundamentals.Cambridge: MIT Press

[11] Schell, Jesse. (2008). The Art Of Game Design: A Book of Lenses.Berlington:Morgan Kaufmann Publishers

[12] Sholikhah, M. B. (2015). Pengembangan Aplikasi Game Edukasi untuk Membantu Meningkatkan Konsentrasi Siswa Autis. Skripsi. Malang: FT UM

[13] SK Dirjen Dikdasmen No 330/D. D5/KEP/KR/2017 Tentang Kompetensi Inti dan Kompetensi Dasar Mata Pelajaran Muatan Nasional (A), Muatan Kewilayahan (B), Dasar Bidang Keahlian (C1), Dasar Program Keahlian (C2), dan Kompetensi Keahlian (C3). PSMK Kemdikbud (Online), (http://psmk.kemdikbud.go.id), diakses 10 Januari 2018. https://doi.org/10.17509/jmee.v2i1.1149

[14] SK Dirjen Dikdasmen No 330/D/KEP/KR/2017 Tentang Struktur Kurikulum Pendidikan MenengahKejuruan. PSMK Kemdikbud (Online), (http://psmk.kemdikbud.go.id), diakses 10 Januari 2018

[15] Trisna, P., Permana, H., Darmawiguna, I. G. M., Windu, M., \& Kesiman, A. (2014). JA-KO Balinese Pizza: Game Edukasi Interaktif Jaringan Komputer, 3, 80-87. University of Rochester. 2010. Video Games Lead to Faster Decisions that are No Less Accurate, (Online), (http://rochester.edu/news/ show.php?id=3679) diakses tanggal 23 Januari 2020. https://doi.org/10.23887/janapati.v3i2.9808

[16] Waleed Salim Alhalafawy. (2019). The Effect of Mobile Digital Content Applications Based on Gamification in the Development of Psychological Well-Being. iJIM - Vol. 13, No. 8, 2019. https://doi.org/10.3991/ijim.v13i08.10725

\section{Authors}

Heri Pratikto is a Lecturer at the Management Department, Faculty of Business Economics, Universitas Negeri Malang.

Rizal Hanafiya is a Student at the Informatics Engineering Education Bachelor Degree, Faculty of Engineering, Universitas Negeri Malang.

Muhammad Ashar is a Lecturer at the Electrical Engineering Department, Faculty of Engineering, Universitas Negeri Malang. Email: Muhammad.ashar.ft@um.ac.id

Muhammad Iqbal Akbar is a Lecturer at the Electrical Engineering Department, Faculty of Engineering, Universitas Negeri Malang.

Yudi Tri Harsono is a Lecturer at the Faculty of Psychology Education, Universitas Negeri Malang.

Article submitted 2021-01-28. Resubmitted 2021-02-18. Final acceptance 2021-02-20. Final version published as submitted by the authors. 